\title{
Anywhere but here: Experiences of islandness in Pearl River Delta island tourism
}

\author{
Zhikang Wang \\ Department of Geography, University of Hong Kong, Hong Kong \\ wangzhk@connect.hku.hk
}

\section{Mia M. Bennett}

Department of Geography \& School of Modern Languages \& Cultures (China Studies Programme), University of Hong Kong, Hong Kong mbennett@hku.hk (corresponding author)

\begin{abstract}
This study considers the phenomenology of 'islandness' by analysing the experiences of tourists, islanders, and migrant tourism workers on two Chinese islands in the South China Sea. Although we begin by presuming place to be a phenomenological concept centring on 'being-in-the-world', we find that people's experiences both on and off the islands of Dong'ao and Wailingding engender a desire to 'be-in-many-worlds' at once. Findings drawn from three months of ethnographic fieldwork suggest that while tourists privilege 'being-at-the-seaside', long-term residents prioritize being both 'on' and 'off the island. Meanwhile, migrant tourism workers' sense of islandness emerges from 'being-at-theseaside' and 'being-on-the-island'. In all cases, we find that islands challenge people's desires to dwell in just one specific place to which they have an attachment. We argue that this liminal place attachment arises partly because the physical geography of islands, being surrounded by the sea, facilitates movement and may prompt a longing for elsewhere. Our findings have consequences for the phenomenology of place, which assumes that people have an innate desire to be somewhere. Yet thinking through and from islands shows that people equally wish to be somewhere else, too. The manifold human experiences of islandness underscore the need for a more relational phenomenology of place based not just on 'being-in-the-world', but rather 'in-many-worlds' at once.
\end{abstract}

Keywords: China, experience, islands, island tourism, islandness, Pearl River Delta, phenomenology, place

https://doi.org/10.24043/isj.115 • Received March 2019, accepted March 2020

(C) 2020 - Institute of Island Studies, University of Prince Edward Island, Canada.

\section{Introduction}

Island tourism, long an exemplar of the classic 'sun and surf vacation (Butler, 1993), is growing as increasing numbers of tourists from developing countries like China seek to escape the pressures of urban life and relax by the sea. Tourism now serves as the main motor for 
economic development in many small island states and territories (Figueroa \& Rotarou, 2016; Gil-Alana \& Huijbens, 2018; Pratt, 2015). New influxes of people are generating significant sociocultural impacts, too, especially on previously isolated islands (Ou \& Ma, 2017; ParraLópez \& Martínez-González, 2018; Yu et al., 2017). The arrival of tourists, tourism workers, and other 'non-islanders' is affecting how islands are constructed as places, or what is often conceptualized as 'islandness' (Selwyn, 1980; Stratford, 2008; Kelman, 2018; Bustos \& Román, 2019; Grydehøj, 2020). Islandness is recognized as a "metaphysical sensation that derives from the heightened experiences that accompany the physical isolation of island life" (Conkling, 2007, p. 200). Yet as our study shows, islandness may equally derive from experiences both on and off the island, pointing to the deep connectedness of island life to other places, particularly the sea and the mainland.

Putting human encounters at the heart of how we understand islandness and broader processes of place-making, our ethnographic research examines two islands where tourism is transforming island lives: Dong'ao and Wailingding, both located at the mouth of the Pearl River Delta, off the coast of southern China. The two islands serve as popular weekend getaways for the nearby city of Zhuhai in Mainland China. Their proximity to the mainland allows for constant flows of not only tourists, but also residents and migrant tourism workers. Together, these three groups constitute the two islands' dominant demographics, whose imaginings of the islands we analyse.

We approach our research with two main objectives. First, we aim to examine the experiences and performances of tourists, local islanders, and migrant tourism workers on these two islands, offering a novel empirical contribution to an island studies literature that has often neglected non-Western experiences. To date, case studies of islands such as those off the coasts of Great Britain and Canada and in the Mediterranean, Oceania, and the Caribbean have dominated island studies (Grydehøj, 2020). Second, we explore how these three demographics' experiences affect their constructions of islandness, bringing hermeneutic phenomenology and place theory to bear on islandness. In so doing, we recentre the phenomenological process of 'being-in-the-world' (Tuan, 1971) to studies of islandness and place-making. We also build on Rakić and Chambers' (2012) argument that people make sense of the lived world through their experiences of it. Focusing on people's experiences of 'being' — which in our study, encompasses traveling, dwelling, and working-is timely, for as increasing mobility transforms both the accessibility and frequency of travel to islands, different demographics may come to construct islands as places in different ways. Islands are no longer remote escapes detached from the rest of the world, if they ever were. Our analysis is therefore embedded within the relational turn, aiming to reflect upon experiences of 'islandness' in a fluid, mobile, and interconnected society.

Exploring how tourism is enjoyed, practiced, and understood by visitors and residents on Dong'ao Island and Wailingding Island can provide insights into island tourism while informing theoretical considerations of how islands are constructed as places with specific particularities and meanings beyond simply being small landmasses surrounded by the sea. These two case studies bear direct relevance for research into the motives and interests of Chinese tourists, which remain weakly understood despite the sector's rapid expansion in recent years (Keating \& Kriz, 2008). With over 6,000 islands, many of which are popular domestic and international tourism destinations, China represents a significant gap in both empirical and conceptual understandings of island tourism (Grydehøj, Heim, \& Zhang, 2017). 
The South China Sea in general and the Pearl River Delta in particular hold a large portion of these 6,000 islands, many of which are experiencing significant tourism development. In 2017 in China, 153.2 million domestic tourists travelled to island destinations, including Hainan Island and 12 major island county-level administrative districts, and these island visits contributed 170.9 billion CNY ( US $\$ 24.7$ billion) to the country's tourism industry (Department of Tourism of Hainan Province, 2017; Ministry of Natural Resources of the People's Republic of China, 2018).

Our study is informed by over three months of ethnographic observations made by the first author on Dong'ao Island and Wailingding Island during repeat visits between October 2017 and August 2018. Throughout the course of his fieldwork, the first author embedded himself into the two field sites and witnessed tourism practices, including tourists' recreational activities, islanders' and migrant tourism workers' everyday lives, and islanders' behaviours towards tourists. A total of 53 interviews were conducted with members of these three groups on the two islands. Interviews took place in Chinese and were translated into English by the authors. They were also supplemented by informal, 'on-the-fly' conversations. Taken together, the insights gained from these observations, interviews, and conversations inform our conceptualization of islandness and place-making within a distinctly Chinese context.

\section{Place, performance, and islandness}

Islands, in their most elemental form, can be defined as bodies of land surrounded by the sea (Hay, 2013). More precisely, they can be categorized as landmasses smaller than a continent surrounded by water (Sharpley, 2012). Islands' diminutive size and littoral status are important not just for their physical geography, but for how they are imagined as places, too-especially by tourists who come to visit and experience islands that have long only existed in their imaginations. Baldacchino (2006) considers remoteness, isolation, and geographic peripherality as important characteristics of islands and island tourism. Hay (2013), too, finds that aquatic surroundings are integral for islands in processes beyond tourism, such as in constructing islanders' identities. Across these studies, the focus is on whether islands are ontologically distinct from other geographic entities.

Rather than start from the vantage point of islands, we consider the experiences that people have both on and off islands in order to understand islandness (Baldacchino, 2008; Baldacchino \& Clark, 2013; Hay, 2006). We interpret these experiences through the lens of 'performance', which refers to the embodied modes of active consumption, or bodily sensations and affects (Rakić \& Chambers, 2012; Urry \& Larsen, 2011). In the case of tourists, this might involve purchasing souvenirs or dining out, while for residents, it might involve going about daily life. Finally, for migrant tourism workers, 'performance' might involve working as a tour guide or a shop vendor. Rather than reflecting static and independent social structures and entities, performative acts turn a place into a 'reality-in-becoming' (Cohen \& Cohen, 2012, p. 2183). Since performative acts and experiences are always changing, so too are places, which are processual and not fixed.

By focusing on the phenomenology rather than the ontology of islands, we build on the work of Hay (2006), who identifies three fault lines within island studies: 1) the isolation versus connectedness of islands; 2) the vulnerability versus tenacity of islands; and 3) the status of islands as 'real' versus 'metaphor'. These divisions, he notes, parallel those found within 
place theory, which is why islands are provocative grounds for thinking through contemporary conceptions and constructions of place. In order to theorize both place and islandness, we interrogate people's phenomenological experiences of islandness, bearing in mind that they often yearn to not only escape to islands, as in the case of tourists, but also from them, as in the case of residents (and sometimes migrant tourism workers, too).

Cognizant of Baldacchino's (2008) concern that island studies have traditionally neglected relations between islanders and mainlanders, we thus adopt a more relational view of both islands and islandness (e.g. Pugh, 2018). It is not just tourists whose imaginings and experiences of a destination bear importance for how it is constructed as a place: the perceptions of those who live and work in host communities matter, too. In a world increasingly characterized by heightened mobilities, places are dynamically constructed over time not only by full-time residents, but equally by part-time residents and tourists. From this point of departure, our effort aims to contribute to the emergent literature within island studies exploring relations between islands and the mainland (Kang, 2011; Vannini et al., 2009), islands and cities (Grydehøj, 2015), islands and archipelagos (Stratford et al., 2011), and land and sea (Johnson, 2020). Growing acknowledgement of the complex ties binding islands to other places challenges the long-standing assumption that islands are remote, resilient, and peripheral (Pugh, 2018). We build upon these recent theoretical advances in island studies to explore what new conceptions of islandness can demonstrate about the modern human experience of place.

Place-concisely defined as being made when meaning is added to space (Keough, 2010) - is an integral geographic lens for contemporary sociocultural studies (Cresswell, 2012). Place lies at the centre of meanings constructed by human experiences of 'being-inthe-world'. Its scale can range from the micro to the macro, from the well-worn corners of a home to a neighbourhood, city, region, and nation-state (Tuan, 1975). Place can also be said to comprise location, locale and sense of place (Anderson, 2015). Given the preponderance of island studies focused on the more physical aspects of location and locale, we pay attention to the third of these features. Sense of place can be interpreted as both attachment (Manzo \& Devine-Wright, 2013) and an identity constructed by people (Mendoza \& Morén-Alegret, 2013). Islandness forms one type of 'sense of place', even though the place attachments formed by tourists can differ significantly from those of residents (Martin \& Storr, 2009). People express different levels of need for place dependence, or a feeling of rootedness and stability within space. Indeed, tourists may actually be motivated to travel because they long to experience a certain uprootedness. Yet it is generally assumed that most humans will at some point form a place attachment somewhere.

An innate yearning to be in the world - to reside and dwell in a particular part of Earth, in a Heideggerian sense-is often presumed within phenomenologies of place. Coates and Seamon $(1984$, p. 6) assert, 'Phenomenological research [...] indicates that the notion of place crystallizes and focuses one essential aspect of human existence- the inescapable requirement to always be somewhere'. Tourism studies, however, indicate that humans often wish as much to travel somewhere as to dwell somewhere. Of course, this desire for mobility is not incommensurate with dwelling, which has always involved 'belongingness and travelling' (Urry, 2000, p. 157, qtd. in Pons, 2003, p. 50). While tourists are assumed to be on the move, their ability, too, to dwell and form place-attachments is increasingly recognized in lieu of seeing their experiences as banal and meaningless (Lew, 2003; Pons, 2003). Tourists form their own imaginings and experiences of island places from the authentic and indigenous, as 
with the Galápagos Islands (Hennessy \& McCleary, 2011), to the artificial and post-modern, as with 'The World' islands off Dubai (Gupta, 2015).

Yet non-tourists residing or working in tourist destinations, particularly islands, may equally wish to be on the move like tourists, too, and aspire to leave their homes for the mainland even if only temporarily. Place theories can thus also play an important role in unpacking the construction of sites which tourists might view as destinations to travel to, but which residents view as homes to travel from. As people dwell (whether permanently or temporarily) within more places around the world over the course of their lifetimes, they may form place attachments to more locations and demonstrate a greater tendency to 'be-in-manyworlds' rather than simply be in the world. Rakić and Chambers (2012) suggest that places are not static or objectively observed but rather individually and collectively experienced and constructed as part of the phenomenological process of humans' 'being-in-the-world' (Tuan, 1971). We might venture that places are also increasingly experienced by people who inhabit many worlds at once.

\section{Case studies: Dong'ao Island and Wailingding Island}

Although studies of island tourism in Greater China remain underrepresented within the wider literature on island tourism, a few key destinations have been analysed. Case studies include Hainan Island (Ou \& Ma, 2017; Sun, Geng-Qing Chi, \& Xu, 2013), which the Chinese government is promoting as an international tourism destination via the introduction of a 30-day visa-free entry policy for visitors from 59 countries; Taiwan (Kang, 2011; Yu et al., 2017) and its surrounding islets (Chao \& Chao, 2017; Lee et al., 2017); and islands in the Pearl River Delta (Hong, 2017; Hong, 2018). Although only partly comprised of islands, Hong Kong and Macau, China's two Special Administrative Regions (SARs) in the Pearl River Delta, have also attracted attention within island tourism studies (Kwong \& Wong, 2017; Leung et al., 2017; Sheng, 2016; Sheng, Tang, \& Grydehøj, 2017). The Pearl River Delta has played a vital role in the opening of the Chinese economy since at least the 1980s, when Deng Xiaoping established a special economic zone (SEZ) in Shenzhen directly across from Hong Kong. The delta now forms an important area for tourism development, particularly within the Chinese government's Guangdong-Hong Kong-Macau Greater Bay Area plan to develop a new 'megacity region' (Hui, Li, Chen, \& Lang, 2018).

Dong'ao Island and Wailingding Island lie within the Pearl River Delta and form part of the Wanshan Archipelago, which lies to the southeast of Zhuhai, a metropolis of 1.6 million people known as the 'City of a Hundred Islands'. The Wanshan Archipelago has generally received little attention within tourism studies. Representing two key exceptions, however, are Hong's $(2017,2018)$ studies of how island tourism facilitates connections, both concrete and abstract, between Zhuhai's surrounding islands and the mainland. Our analysis complements his observations by critiquing the experiences, performances, and perceptions of tourists, residents, and migrant tourism workers on Dong'ao Island and Wailingding Island (Figure 1), two of the most popular islands to visit in the Wanshan Archipelago among residents of Zhuhai. 


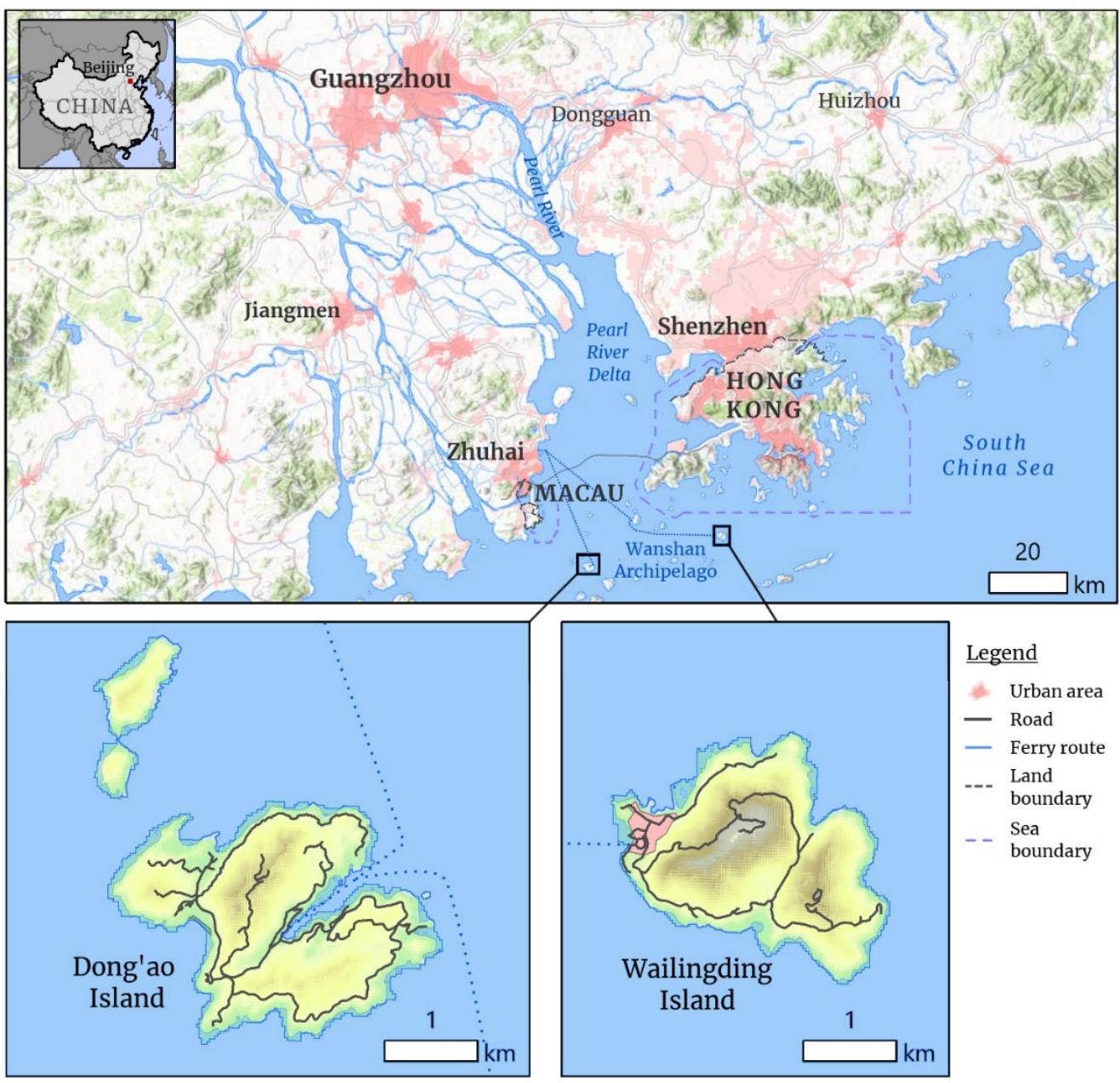

Figure 1. Map of Dong'ao Island and Wailingding Island in the Pearl River Delta. Data sources: ESRI, Natural Earth Data, and Open Street Map.

Wailingding Island and Dong'ao Island represent symbols of leisure and unspoiled nature and form vital components of the 'romantic' reputation of Zhuhai for which they serve as 'weekend havens', yet the two islands exhibit contrasting traits (Hong, 2017). Closer to Hong Kong than Mainland China, Wailingding was once an island that evaded oversight by both Mainland authorities and the Hong Kong government. Gambling and prostitution were rife, and investments often had questionable ties as evinced by the construction of residential buildings (many of which housed prostitutes and/or mistresses), casinos, and hotels. Following the handover of Hong Kong from the United Kingdom back to China in 1997, the People's Republic of China (PRC) government generally succeeded in eliminating gambling and prostitution on Wailingding. In the absence of these businesses, a tourism industry capitalizing on the island's natural beauty took off, drawing sun-, sea-, and sand-seeking tourists. Companies such as Gree Group, a large state-owned enterprise (SOE) based in Zhuhai, began investing in hotels. At the same time, many islanders rented out their residential buildings to migrant tourism workers from other parts of Guangdong Province, in which Zhuhai and the Pearl River Delta are located, as well as from inner provinces such as Sichuan and Hunan. A decade of modernization, urbanization, and gentrification has generated a mature tourism sector in which migrants typically manage tourism practices and investments originate from outside the island rather than from local hosts. 
Compared to Wailingding, Dong'ao Island demonstrates the more commonly observed stages of tourism development involving a trajectory from exploration to development and consolidation over time (Butler, 1980). The island has transformed from attracting fishing tourists in the early days to building up more mass tourism activities. Today, tourism on Dong' ao centres on Nansha Bay, which is home to a 'diamond beach' with high-quality sand and a plethora of coastal recreational activities. There is also a luxury seaside resort called the Gree Dong'ao Hotel (another Gree Group investment). The local community centred in Dong'ao Village is contending with issues typical of islands experiencing tourism expansion, including a sociocultural transition from a rural fishing island to a tourism-dependent economy more integrated with nearby urban society on the mainland. As this integration occurs, tourists and islanders increasingly circulate between the island and the mainland. To a lesser extent, migrant tourism workers, who tend to have relocated from farther away, also go back and forth. The heightened mobilities of these three groups of people whose experiences and performances contribute to place-making processes on the island problematize not only ideas of islandness, but also assumptions of the human need for a rooted sense of place, as we next explore. The dominance of movement and flows in how people form place-attachments to the island also points to the importance of features not specifically part of the inhabited place-in this case, the sea surrounding the island-in shaping how places are imagined, experienced, and constructed.

Table 1. Different groups' experiences of islandness, their form of 'being-in-the-world', and their construction of island places.

\begin{tabular}{|l|l|l|l|}
\hline & Experience & $\begin{array}{l}\text { Form of 'being-in- } \\
\text { the-world' }\end{array}$ & Island place \\
\hline Tourists & $\begin{array}{l}\text { Seaside relaxation and } \\
\text { bonding }\end{array}$ & $\begin{array}{l}\text { 'Being-at-the- } \\
\text { seaside' }\end{array}$ & Seaside vacationlands \\
\hline Islanders & $\begin{array}{l}\text { Living on the island, } \\
\text { fishing, and gathering food }\end{array}$ & 'Being-on-the-island' & Island homes \\
\cline { 2 - 4 } & Traveling to the mainland & 'Being-off-the-island' & Island part-homes \\
\hline $\begin{array}{l}\text { Migrant } \\
\text { tourism } \\
\text { workers }\end{array}$ & $\begin{array}{l}\text { Employment in the } \\
\text { tourism industry }\end{array}$ & $\begin{array}{l}\text { 'Being-at-the- } \\
\text { seaside' }\end{array}$ & Workplaces \\
\cline { 2 - 5 } & Living on the island & 'Being-on-the-island' & Island second homes \\
\hline
\end{tabular}

\section{Constructing (and deconstructing) phenomenologies of islandness}

\subsection{Tourists, islanders, and migrant tourism workers}

On both Dong'ao Island and Wailingding Island, three main demographics can be identified: island residents, tourists, and migrant tourism workers. Over the course of 53 interviews with members of these groups, a variety of ways of experiencing islandness and islands as places emerged. We distil the phenomenology of islandness into three main categories: 'being-atthe-seaside', 'being-on-the-island', and 'being-off-the-island' (Table 1). Tourists' dominant experience of islands involves 'being at the seaside', while for islanders, it is both being on and off the islands. Migrant tourism workers' experiences comprise both 'being-at-theseaside' and 'being-on-the-island', demonstrating an overlap with tourists. These 
experiences - all of which notably involve different ways of interacting with and moving across the physical land- and seascapes - inform three different constructions of island places. Tourists view the islands as 'seaside vacationlands', islanders view them as 'island part-homes', and migrant tourism workers view them as both 'workplaces' and 'island second homes'. To deconstruct this diverse phenomenology of island places and islandness, we next explore in detail the experiences of tourists, islanders, and migrant tourism workers.

\subsection{Tourists' 'seaside vacationlands'}

Tourists construct the islands as 'seaside vacationlands', and the element of 'the sea' is central to their experiences. Tourists sail by ferry across the sea- a geographical entity which serves as both a boundary and gateway for islands (Hay, 2013). Visitors to Dong'ao and Wailingding tend to enjoy coastal activities rather than the islands' terrestrial landscapes. They also do not pay much heed to the islands' peripherality or isolation. In fact, so long as the sea is nearby, they could in some sense be 'anywhere'. Interviewed tourists appeared to take little notice of the idiosyncrasies of the island where they were holidaying, whether Dong' ao or Wailingding. Largely, they viewed their experiences of island tourism as similar to what they might be doing at any seaside destination, whether or not an island. Tourists' experiences of the two islands, which are analogous despite the two islands' contrasting histories of development, privilege leisure activities focused on the sea and bonding with their companions. The following quotes exemplify typical responses received from tourists when they were asked about the most memorable aspects of their trips.

To be honest, there is not much to see or do here. What we did most was rest in the Dong'ao Hotel, you know, swimming in the pool and eating at the buffets. The seafood was not bad in the buffet dinner, but I preferred it when we bought the ingredients at the dock today-it felt fresher. Hmm... then the beach was pretty good, we took a walk by sunset yesterday. It's great to take a vacation with my family. I'm about to enter my senior year after this summer. You know how stressful preparing for the college entrance examination is, right? It's good to take a break and enjoy some time with my parents and grandparents. (Tourist, male, aged 18, high school student, visiting Dong'ao with family)

We came here intending for our little girl to see the sea for the first time. She's never seen the sea before. We are from Ningxia Province [an inland province in northwest China]. My wife and I have been to seaside before, but that was before our daughter was born. She loved it and asked me whether we could stay for one more day this morning. Yesterday afternoon she had great fun at the beach, and so did I. (Tourist, male in his 30s, visiting Dong'ao with his wife and daughter)

I am from the inland, so it's always exciting to see the sea. I liked walking by the sea in the morning, everything was so peaceful. I would say that teenagers might not like it here as much as we do because it lacks excitement, you know. Relaxation and peace may not be 'the thing' for young people, right? But for me, it was perfect. (Tourist, female in her 60s, retired, visiting Wailingding with her husband) 


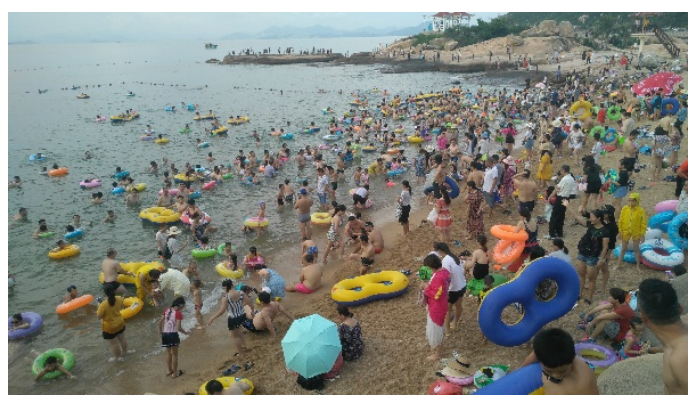

Figure 2. Tourists swimming on Wailingding Island, August 2018.

These interviews indicate that across diverse age groups and demographics, tourists find pleasure in the sea, the beach, and coastal activities (and fresh seafood, too). Participatory observation also suggests that among tourists' activities, swimming and seafood dinners form two of the most popular activities of tourists (Figure 2). Many also appreciate the peaceful atmosphere and slow pace of island life, which they can enjoy with friends, family, or colleagues. Interviewees reported that taking their family members-for example, young children or retired parents - to enjoy a vacation and bond with each other forms their main motivation for visiting the islands, as some of the interview excerpts above highlight. Other visitors to the islands come to participate in company team-building activities, which also generally take place at the shore (Figure 3).

Tourists are normally active along the beaches and on the few main streets of the two islands, where restaurants and hotels are located. They seldom venture to other parts of the islands through activities such as hiking, for instance. In fact, hiking appears unpopular despite offering a direct way to explore and interact with local island landscapes. Yet interacting directly with the terrain may not be of interest to most tourists, who rarely mention the particular characteristics of either island whether social or environmental. In response to one key question posed- “What are your understandings of an 'island' or 'island tourism' after your trip here?- tourists marginalized the geographical specificities of the island and instead emphasized the sea, as illustrated by the following excerpt:

I have never considered what an island is, if that's what you are asking. We just came here to spend some time together [as a family] since it's my boy's summer vacation, and his mom and I can put together a few days off. We learned that this island is not far, and there is a pretty good hotel here where we can relax. So we come, you know, just to get away. I guess traveling to an island means enjoying the sea and beach, the seafood, nothing too special, really. (Tourist, male in his 30s, visiting Dong'ao with his wife and son)

The man's response underplays the importance of the island in contrast to the sea. Notably, he also recounts the experience of traveling across the water to reach the island. The watery surroundings act as a conduit allowing "mobile human and non-human elements and affects" to be "imagined, encountered, and produced" (Steinberg \& Peters, 2015, p. 256). The water forms a connective tissue bringing together the mainland and the island. It also serves as the main geographical feature around which tourists construct their idea of islandness rather than the island itself. 


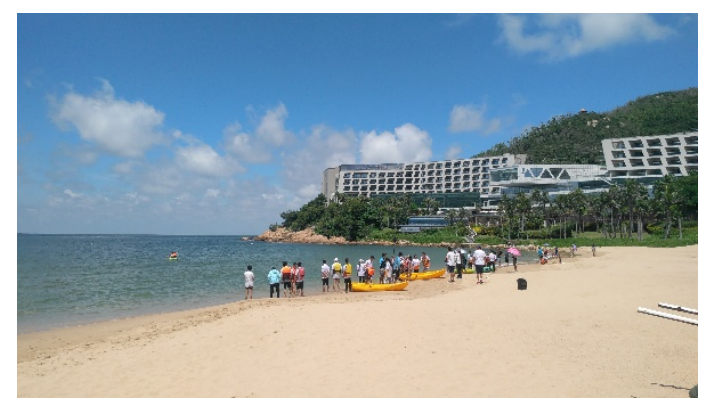

Figure 3. Employees engaging in company team-building on Dong'ao Island, July 2018.

\subsection{Islanders' 'homes' and 'part-homes'}

Island residents' primary perspective of the island is one of home. Unlike tourists, islanders possess local knowledge of natural attributes and sociocultural characteristics that are essential for living on the islands. This intimate awareness of the islands' natural and social environments is accumulated through lived experiences involving both appreciation and detestation. These more nuanced, less leisure-focused views of islands as 'home' compared to tourists' perspectives are expressed in the following excerpts from informal conversations with long-time residents on both islands:

I grew up here on the island. Though I left for school nearly ten years ago, I believe I still know everything about the island and everyone here. If you are going to buy some seafood, you can ask me to help you. I know how to pick good ingredients. And everyone knows me-I wouldn't take advantage [of you]. [...] It's going to rain tomorrow, but the ferry won't be suspended, as there should be no wind. (Islander, female in her 20s, from Wailingding)

I never get tired of looking at the sea. We live off of it. For example, these shells are just there after each ebb. If we find a few, we can eat them ourselves. If more, like today, I can sell to the seafood dealers and provide for my family. This is not as good as life in the city, of course; sometimes it's very tiring. But I like what I have [...]. I tried to work in the city but that didn't work out well, so I returned home. I prefer life here, it's calm. Although, it is terrible when typhoon hits-really tough for a few days. (Laughs) (Islander, female in her 30s, from Dong'ao)

The 'smallness' of islands makes it easy for local residents to 'know everything and everyone'. They refer to the islands as homes while both appreciating and complaining about island life, which can become banal, as with life anywhere. When asked what they like about the islands, islanders tend to reply impatiently, as the below quote evinces:

An island is like this: not much excitement, not much to do, also, not many worries. An island is an island. It is what is. For those [tourists] who come and ask, 'What's attractive about the island?', it's likely that they will end up dissatisfied with what they enjoy here because they are hoping for too much. (Islander, male in his 50s, from Dong'ao) 
Islanders appear to perceive the island, but not the sea, as a mundane backdrop to their daily lives. They share little of tourists' appreciation for the islands' various seaside amenities and they do not appreciate the shoreline as an attraction or place for leisure. Instead, the island and the sea together provide not just a home, but also sustenance (Figure 4). At the same time as the sea provides for their livelihoods, however, it paradoxically forms both an obstacle to an easier life and an element that supports certain conveniences.

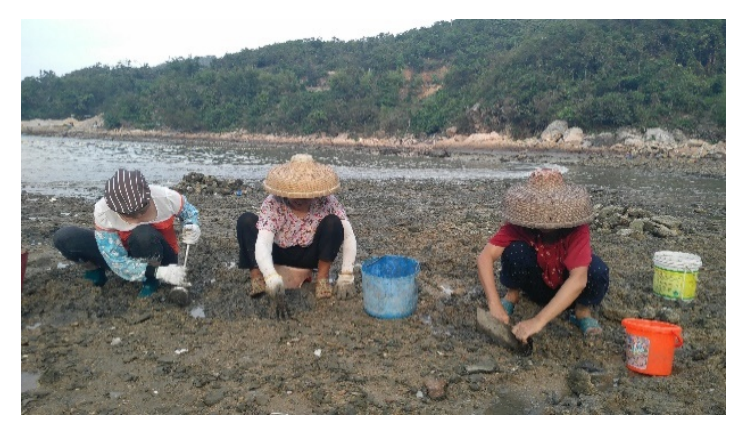

Figure 4. Local islanders looking for shells after the tide has gone out on Dong'ao Island, July 2018.

First, the sea-or more specifically, the ferries and boats that sail across its surface-allows islanders to come and go as they please (weather permitting). A desire to leave the island was prevalent among interviewees. Over the course of living on Dong'ao or Wailingding, islanders build specific attachments to their home involving feelings of fondness on the one hand and frustration and ennui on the other hand that lead them to want to escape to the mainland, which the following quote captures:

The biggest inconvenience of living here is lacking life's necessities: vegetables, groceries, hardware, and other stuff. One example I can tell you is getting haircuts. There are no barbershops here, and that makes me have to return to Zhuhai every two or three weeks just for a haircut [...] But you get used to it. You know, in the past when the power grids didn't reach here, there was no power after 19:00, and we lived here anyway. It's funny thinking back. I mean, it could be really troublesome to have no power during evenings, right? But that was how we lived, and it wasn't that bad. With the [cargo] ship coming in every other day now, at least we have what we need, though weather can affect it a lot. (Islander, male in his 30s, from Dong'ao)

The inability to get haircuts or enjoy uninterrupted electricity underscores island life's inconveniences, which compel islanders to 'return' to the mainland. In their descriptions of the experiences, reference is frequently made to the round-trip journey between Zhuhai City on the mainland and Dong'ao Island, which is described cyclically as a 'return to Zhuhai' and 'return to Dong'ao' instead of going away and coming back home. Recognizing the advantages and disadvantages of both island and city life, islanders remain suspended in a liminal state of constantly returning from one place to the other when negative experiences exceed positive ones. 
While the sea makes possible this perpetual 'return journey', it is made economically possible by tourism. Many islanders participate in the tourism sector even though they express dissatisfaction with the economic opportunities available and feel disturbed by the increasing amount of mass tourism on the islands. On Dong'ao Island, local islanders have materially profited from tourism's development and are able to afford properties in Zhuhai, for instance. Yet they still do not move away from the island completely. The following excerpt summarises a view typical of residents:

Life on the island is quiet and peaceful but inconvenient and repetitive; life on the mainland is more exciting and plentiful but noisy and fast. Both are good and bad in some ways. After some time on the island, you miss the city, and after some time in the city, you want to come back to the island. (Islander, male in his 40s, from Dong'ao)

In this way, the island becomes a 'part home' with experiences of islandness inextricable from experiences of the mainland. The sea both connects and separates the island from the mainland, leading to the need to have a home in each place. Islanders feel a need to be 'on the island' and then subsequently 'off the island', confirming a sense of place tied to 'beingin-many-worlds' at once. Islands therefore do not only see tourists come and go. Islands also push residents to leave, but only temporarily before compelling them to return, too.

\subsection{Migrant tourism workers' 'workplaces' and 'island second homes'}

Islands also attract one other major category of people: migrant workers who arrive in search of economic opportunity rather than leisure. On Dong'ao Island and Wailingding Island, most tourism workers migrated in pursuit of employment after hearing about the location from relatives or acquaintances from their hometowns earning a living there. The majority of migrants originate from other parts of Guangdong Province and the interior provinces of Sichuan and Hunan. Typical jobs include working at a hotel or local seafood restaurant, selling and renting swimsuits and toys for beach activities, and instructing diving and snorkelling classes. Generally, migrants work either as small business owners or as employees at the Gree Group resorts. As in many other tourist destinations, tourism workers have few personal interactions with their customers outside of commercial transactions. They instead view the island as a place to make a living and do not see it as different from working in another location in the tourism business. Arguably, their relative blindness to the islands' idiosyncrasies resembles how tourists perceive islands simply as seaside destinations without attention to their particularities. As explained by a Wailingding hotel proprietor and a Dong'ao barbecue stand owner/fisherman, respectively:

I worked in Zhuhai for two years before coming here back in 2016. I used to run a restaurant and it was not a good experience. The money was just enough for supporting my family. Then I took over this [current] business from one of my friends from back home. I think the business is okay... it's not an easy business for sure, but where can you get away from the struggles, anyway? I need to make money to support my family, and working anywhere that can suffice is fine. (Hotel owner, male in his 30s, on Wailingding Island) 
This barbecue only opens on summer nights when there are lots of people and I have the time, as it is outside the fishing season. Tourists have money, and our food is worth the money since it's fresh from the sea. The business is okay as long as it doesn't rain or become too windy. I don't really talk to them [tourists] much, and they have their friends and don't want to talk to us either. It's just good business. (Barbecue stand owner/fisherman, male in his 20s, on Dong'ao Island)

Both interviewees demonstrate ambivalence to their physical and social surroundings. Given that they were both drawn from their original homes to set up new ones on the islands, the lack of a strong sense of place, at least initially, is to be expected. Yet over time and through the accumulation of experiences of living on the island, some migrant workers do develop a place attachment centring on the temporalities of island life rather than the island's physical attributes. One interviewee described his feelings as follows:

I could get a job in Zhuhai, but I like it here. Running a little business here is about the same money, but life is much more relaxing. Now that I have been on the island long enough, I do not think I am capable of going back to Zhuhai and adjusting to life there. (Snorkelling coach, male, in his 20s, on Wailingding Island)

Coming to the islands initially in search of economic opportunities, migrant tourism workers first see the islands as little different from their origins on the mainland. Yet as their experiences on the islands deepen, they reconstruct the islands from mere workplaces into second homes. This process happens in reverse to that of long-time island residents, who transform both the islands and places on the mainland into part-homes. Regardless, across all three demographics - tourists, islanders, and migrant workers - the fluidity of place is apparent. So, too, is the fact that this dynamism emerges from the ability of people in general, rather than simply tourists, to simultaneously dwell within and travel to and from a place.

\section{Discussion and conclusion: Place for island studies}

We have attempted to show that rather than defining islands as bodies of land surrounded by the sea, 'islandness' can perhaps be better conceived through the experiences of the people who live and work on and travel to and from islands. In our phenomenology of islandness, we delineate three main ways of 'being-in-the-world': 'being-at-the-seaside', 'being-on-theisland', and 'being off-the-island'. The importance of these modes of 'being' varies among tourists, islanders, and migrant tourism workers, as our empirical observations on Dong'ao Island and Wailingding Island reveal. Whereas tourists, in enjoying seaside leisure activities and bonding with companions on the shore, privilege 'being-at-the-seaside', they hold little value for 'being-on-the-island'. In contrast, long-time residents' experiences of islandness focus on the island's actual terrain, where people make their homes and places of work. They yearn to be both 'on' and 'off' the island, resulting in a perpetual return journey between the island and mainland. 'Being-off-the-island' concerns the desire of people to be away from the island while they are on it and is mostly felt by islanders. Though not explored in this paper, it goes without saying that the great majority of island tourists likely also desire to return 
home to the mainland at some point, too. Finally, migrant tourism workers-ironically those who were originally 'off the island'-bring together the two categories of 'being-at-theseaside' and 'being-on-the-island' through their constructions of islandness, in which they turn their workplaces into second homes.

Islanders' yearning to be away from the island — and yet to also return to it when they are off the island - encapsulates a human need to not only 'be-in-the-world' through developing a deep attachment to a specific place, as Tuan (1974) theorizes, but also to 'be-in-many-worlds'. This sentiment is thus not only felt by tourists on the move, but by islanders as well despite the fact that they might normally be perceived as dwelling statically on a single island. Indeed, while islands arguably attract tourists by virtue of 'being away' (Chaperon \& Bramwell, 2013), in our study, islanders appear to value 'being away' as much, if not more, than tourists given that their day-to-day rather than simply leisure needs depend on being able to 'get away'.

Across all three experiences of islandness-'being-at-the-seaside', 'being-on-theisland', and 'being-off-the-island' - there is one constant: the sea. While it promises both a route to and destination for tourists' escapism, the sea acts as an obstacle to islanders who might yearn for more conveniences in their quotidian lives. At the same time, residents' ability to leave the island is largely made feasible thanks to the sea serving as a pathway to and from the mainland. The sea also provides both a means of reaching the island and a means of making a living for the migrant workers who serve up its pleasures to sunburnt, sand-caked tourists. Islands can thus serve as foci for thinking through place in the modern era because they underscore the importance of movement to and from a certain locale-in this case, across the sea-in shaping how place is experienced and constructed.

Our ethnographic research suggests that while tourists, islanders, and migrant tourism workers depend on the ability to move and travel, island places and islandness are ultimately defined by mobility and liminality. While our study has focused on the phenomenology of islands, this finding suggests that closer critique of the interrelations between the phenomenology and ontology of islandness may prove to be a productive line of enquiry. In their proclivity to facilitate movement thanks to being surrounded by the sea, islands generate a yearning for elsewhere that characterizes the modern human experience in which 'being-in-many-worlds' is in fact physically possible thanks to advances in transportation, information and communication technologies, not to mention the acceleration of globalization. Our observations thus contribute to a more humanistic and relational retheorization of 'island' place —and place in general-emphasizing the human experiences of not just 'being-in-the-world', but seeking to 'be-in-many-worlds' at once. If islandness, across various demographics, fosters a desire to be elsewhere, then islandness may be a useful metaphor for the modern condition.

Drawing from our findings, we call for further work within island studies in two main areas. First, while the significance of mobility to islands and constructions of islandness has been acknowledged, less attention has been paid to the temporalities involved in the phenomenology of islands. For instance, while tourists only come for a few days, residents stay for months at a time. Migrant workers might reside on the island even longer since returning to their home province often requires a longer journey than that of residents seeking a brief taste of city life. The patterns of movements to and from islands and the effects of these rhythms on placemaking processes merit attention, especially as questions of the accessibility of islands arise in line with the availability of transportation options (Grydehøj \& Casagrande, 2020; Karampela, Kizos, \& Spilanis, 2014). Second, further studies of both islands and place-making processes 
within China are necessary to determine whether a distinct Chinese version of islandness or place attachment exists. Research within a Western context emphasizes islands' remoteness as the main attraction for tourists (Sharpley, 2012), while experiences relating to the sea form the basis for how islanders construct their island places (Hay, 2013). Our research, however, points to some differences. Chinese tourists may be more attracted to the sea rather than to the island itself, and they may also not be particularly drawn to 'remoteness'. Moreover, for islanders on Dong' ao and Wailingding, isolation is sometimes seen as more of a disadvantage than an advantage, while the island's terrain figures more strongly than the sea in their constructions of islandness. In light of these apparent divergences between Chinese and Western attitudes towards islands and islandness, we encourage further research into how island tourism is practiced and how islandness is imagined in non-Western contexts. Such studies may inform broader theorizations of place-making beyond the well-traversed West.

Finally, we conclude that the phenomenological notion of 'place' is highly productive for critiquing islandness (Hay 2006), as the concept encourages theoretical and empirical attention to people's experiences of 'being-in-the-world'. 'Place' and 'islandness' are aligned, for both are phenomenological in nature and draw from individuals' experiences. The experiences of 'being-at-the-seaside' and being 'on' or 'off-the-island' demonstrate that islands are distinct places phenomenologically, for these sensations cannot be as readily had in locations that are neither small nor surrounded by the sea. Thus, in answer to Hay's (2006) question regarding whether a coherent island studies can be effectively pursued, we conclude that place is indeed well-suited to serve as a humanistic framework for theorizing islands and islandness. Place theory equips scholars with the ability to grapple with the sociospatial and temporal complexities of islandness in an era in which being in 'many worlds' rather than 'the world' appears to be becoming the new norm of the modern human condition. Orthodox phenomenology of place assumes that people have an innate desire to be somewhere. Yet people-whether tourists, islanders, or migrants - may equally wish to be somewhere else, too. A more relational phenomenology of islands and, more broadly, place may help us reckon with the consequences of this wish becoming increasingly realisable for an ever more mobile humanity.

\section{References}

Baldacchino, G., \& Clark, E. (2013). Guest editorial introduction: Islanding cultural geographies. $\quad$ Cultural Geographies, $\quad 20(2), \quad 129-134$. https://doi.org/10.1177/1474474012469594

Baldacchino, G. (2008). Studying islands: on whose terms? Some epistemological and methodological challenges to the pursuit of island studies. Island Studies Journal, 3(1), 37-56.

Baldacchino, G. (2006). Warm versus cold water island tourism: a review of policy implications. Island Studies Journal, 1(2), 183-200.

Bustos, B., \& Román, Á. (2019). A sea uprooted: islandness and political identity on Chiloé Island, Chile. Island Studies Journal, 14(2), 97-114. https://doi.org/10.24043/isj.91

Butler, R. W. (1980). The concept of tourism area cycle of evolution: Implications for management of resources. Canadian Geographer, 24(1), 5-12. 
Butler, R. W. (1993). Tourism development in small islands: Past influences and future directions. In D. G. Lockhart, D. Drakakis-Smith, and J. A. Schembri (Eds.), The Development Process in Small Island States. London: Routledge (pp. 71-91).

Chao, Y.-L., \& Chao, S.-Y. (2017). Resident and visitor perceptions of island tourism: green sea turtle ecotourism in Penghu Archipelago, Taiwan. Island Studies Journal, 12(2), 213228. https://doi.org/10.24043/isj.27

Chaperon, S., \& Bramwell, B. (2013). Dependency and agency in peripheral tourism development. Annals of Tourism Research, 40, 132-154. https://doi.org/10.1016/j.annals.2012.08.003

Coates, G. J. and Seamon, D. (1984) Toward a phenomenology of place and place-making: Interpreting landscape, lifeworld and aesthetics. $\mathrm{Oz}, \quad 6(3)$, 6-9. https://doi.org/10.4148/2378-5853.1074

Cohen, E., \& Cohen, S.A. (2012). Current sociological theories and issues in tourism. Annals of Tourism Research, 39(4), 2177-2202. https://doi.org/10.1016/j.annals.2012.07.009

Conkling, P. (2007). On islanders and islandness. Geographical Review, 97(2), 191-201. https://doi.org/10.1111/j.1931-0846.2007.tb00398.x

Cresswell, T. (2012). Geographic thought: A critical introduction: New York: John Wiley \& Sons.

Department of Tourism of Hainan Province. (2017). Tourism statistics for December 2017 [2017 年 12 月 旅游统 计 ]. Retrieved from http://lwt.hainan.gov.cn/xxgk 55333/lytj/2017data/201804/t20180410 2436928.html

Figueroa, E., \& Rotarou, E. S. (2016). Tourism as the development driver of Easter Island: the key role of resident perceptions. Island Studies Journal, 11(1), 245-264.

Gil-Alana, L. A., \& Huijbens, E. H. (2018). Tourism in Iceland: Persistence and seasonality. Annals of Tourism Research, 68, 20-29. https://doi.org/10.1016/j.annals.2017.11.002

Grydehøj, A. (2020). Critical approaches to island geography. Area, 52(1), 2-5. https://doi.org/10.1111/area.12546

Grydehøj, A. (2015). Island city formation and urban island studies. Area, 47(4), 429-435. https://doi.org/10.1111/area.12207

Grydehøj, A., \& Casagrande, M. (2020). Islands of connectivity: Archipelago relationality and transport infrastructure in Venice Lagoon. Area, 52(1), 56-64. https://doi.org/10.1111/area.12529

Grydehøj, A., Heim, O., \& Zhang, H. (2017). Islands of China and the Sinophone world. Island Studies Journal, 12(2), 3-6. https://doi.org/10.24043/isj.41

Gupta, P. (2015). Futures, fakes and discourses of the gigantic and miniature in'The World'islands, Dubai. Island Studies Journal, 10(2), 181-196.

Hay, P. (2013). What the sea portends: A reconsideration of contested island tropes. Island Studies Journal, 8(2), 209-232.

Hay, P. (2006). A phenomenology of islands. Island Studies Journal, 1(1), 19-42.

Hennessy, E., \& McCleary, A. L. (2011). Nature's Eden? the production and effects of pristine nature in the Galápagos Islands. Island Studies Journal, 6(2), 131-156.

Hong, G. (2020). Islands of enclavisation: Eco-cultural island tourism and the relational geographies of near-shore islands. Area, 52(1), 47-55. https://doi.org/10.1111/area.12521 
Hong, G. (2017). Locating Zhuhai between land and sea: A relational production of Zhuhai, China, as an island city. Island Studies Journal, 12(2), 7-24. https://doi.org/10.24043/isj.16

Hui, E. C., Li, X., Chen, T., and Lang, W. (2018). Deciphering the spatial structure of China's megacity region: A new bay area-The Guangdong-Hong Kong-Macao Greater Bay Area in the making. Cities. https://doi.org/10.1016/j.cities.2018.10.011

Jamal, T., \& Robinson, M. (2009). The SAGE Handbook of Tourism Studies. London \& New York: Sage.

Johnson, H. (2020). Islands of design: Reshaping land, sea and space. Area, 52(1), 23-29. https://doi.org/10.1111/area.12477

Kang, P. (2011). China's island frontier: Geographical ideas on the continent-based nationalist narratives on Taiwan. Island Studies Journal, 6(1), 29-44.

Karampela, S., Kizos, T., \& Spilanis, I. (2014). Accessibility of islands: towards a new geography based on transportation modes and choices. Island Studies Journal, 9(2), 293-306.

Kelman, I. (2018). Islandness within climate change narratives of small island developing states (SIDS). Island Studies Journal, 13(1), 149-166. https://doi.org/10.24043/isj.52

Keough, S.B. (2010). The importance of place in community radio broadcasting: A case study of WDVX, Knoxville, Tennessee. Journal of Cultural Geography, 27(1), 77-98. https://doi.org/10.1080/08873631003593265

Kwong, Y.H., \& Wong, M.Y. (2017). State size and democratization in hybrid regimes: the Chinese island cities of Macau and Hong Kong. Island Studies Journal, 12(2), 113-126. https://doi.org/10.24043/isj.36

Lee, S.-H., Huang, W.-H., \& Grydehøj, A. (2017). Relational geography of a border island: local development and compensatory destruction on Lieyu, Taiwan. Island Studies Journal, 12(2), 97-112. https://doi.org/10.24043/isj.33

Leung, A., Tanko, M., Burke, M., \& Shui, C.S. (2017). Bridges, tunnels, and ferries: connectivity, transport, and the future of Hong Kong's outlying islands. Island Studies Journal, 12(2), 61-82. https://doi.org/10.24043/isj.24

Lew, A. A. (2003). Editorial: Tourism in places and places in tourism. Tourism Geographies, 5(2), 121-122. https://doi.org/10.1080/1461668032000068252

Manzo, L. C., \& Devine-Wright, P. (2013). Place attachment: Advances in Theory, Methods and Applications. New York: Routledge.

Martin, N. P., \& Storr, V. H. (2009). Whose Bay Street? Competing narratives of Nassau's city centre. Island Studies Journal, 4(1), 25-42.

Mendoza, C., \& Morén-Alegret, R. (2013). Exploring methods and techniques for the analysis of senses of place and migration. Progress in Human Geography, 37(6), 762-785. https://doi.org/10.1177/0309132512473867

Ministry of Natural Resources of the People's Republic of China. (2018). 2017 Island Statistical Survey Bulletin. [2017 年海岛统计调查公报]. Retrieved from http://gi.mnr.gov.cn/201807/t20180727 2156215.html

Ou, Z., \& Ma, G. (2017). Marginalisation of the Dan fishing community and relocation of Sanya fishing port, Hainan Island, China. Island Studies Journal, 12(2), 143-158. https://doi.org/10.24043/isj.31 
Parra-López, E., \& Martínez-González, J. A. (2018). Tourism research on island destinations: a review. Tourism Review, 73(2), 133-155. https://doi.org/10.1108/tr-03-2017-0039

Pons, P.O. (2003). 'Being-on-holiday: Tourist dwelling, bodies and place. Tourist Studies, 3(1), 47-66. https://doi.org/10.1177/1468797603040530

Pratt, S. (2015). The economic impact of tourism in SIDS. Annals of Tourism Research, 52, 148-160. https://doi.org/10.1016/j.annals.2015.03.005

Pugh, J. (2018). Relationality and island studies in the Anthropocene. Island Studies Journal, 13(2), 93-110. https://doi.org/10.24043/isj.48

Rakić, T., \& Chambers, D. (2012). Rethinking the consumption of places. Annals of Tourism Research, 39(3), 1612-1633. https://doi.org/10.1016/j.annals.2011.12.003

Selwyn, P. (1980). Smallness and islandness. World Development, 8(12), 945-951. https://doi.org/10.1016/0305-750x(80)90086-8

Sharpley, R. (2012). Island tourism or tourism on islands? Tourism Recreation Research, 37(2), 167-172. https://doi.org/10.1080/02508281.2012.11081701

Sheng, L. (2016). The transformation of island city politics: The case of Macau. Island Studies Journal, 11(2), 521-536.

Sheng, N., Tang, U. W., \& Grydehøj, A. (2017). Urban morphology and urban fragmentation in Macau, China: Island city development in the Pearl River Delta megacity region. Island Studies Journal, 12(2), 199-112. https://doi.org/10.24043/isj.25

Steinberg, P., \& Peters, K. (2015). Wet ontologies, fluid spaces: Giving depth to volume through oceanic thinking. Environment and Planning D: Society and Space, 33(2), 247264. https://doi.org/10.1068/d14148p

Stratford, E. (2008). Islandness and struggles over development: A Tasmanian case study. Political Geography, 27(2), 160-175. https://doi.org/10.1016/j.polgeo.2007.07.007

Stratford, E., Baldacchino, G., McMahon, E., Farbotko, C., \& Harwood, A. (2011). Envisioning the archipelago. Island Studies Journal, 6(2), 113-130.

Sun, X., Geng-Qing Chi, C., \& Xu, H. (2013). Developing destination loyalty: The case of Hainan Island. Annals of Tourism Research, 43, 547-577. https://doi.org/10.1016/j.annals.2013.04.006

Tuan, Y.F. (1971). Geography, phenomenology, and the study of human nature. Canadian Geographer/Le Géographe canadien, 15(3), 181-192. https://doi.org/10.1111/j.1541_ 0064.1971.tb00156.x

Tuan, Y.F. (1974). American space, Chinese place. Harper's Magazine, 8.

Tuan, Y.F. (1975). Place: An experiential perspective. Geographical Review, LXV(2), 151-165.

Urry, J. (1995). Consuming Places. Hove, UK: Psychology Press.

Urry, J. (2000). Sociology beyond societies: Mobilities for the Twenty-First Century. London: Routledge.

Urry, J., \& Larsen, J. (2011). The Tourist Gaze 3.0: London: Sage.

Vannini, P., Baldacchino, G., Guay, L., Royle, S. A., \& Steinberg, P. E. (2009). Recontinentalizing Canada: Arctic ice's liquid modernity and the imagining of a Canadian archipelago. Island Studies Journal, 4(2), 121-138.

Yu, C.-P., Huang, Y.-C., Yeh, P.-F., \& Chao, P.-H. (2017). Residents' attitudes toward island tourism development in Taiwan. Island Studies Journal, 12(2), 159-176. https://doi.org/10.24043/isj.32 